\title{
Role of mesenchymal stem cells and their culture medium in alleviating kidney injury in rats diabetic nephropathy
}

Amal Al-Shahat Ibrahim, Manal Mohammad Morsy ${ }^{1}$, Safwat E. Abouhashem², Omnia Aly ${ }^{3}$, Norhan A. Sabbah ${ }^{4}$ and Nermin Raafat ${ }^{4^{*}}$ (D)

\begin{abstract}
Background: Diabetic nephropathy (DN) is considered as one of the most serious complications resulting from diabetes mellitus and end-stage of renal failure globally. Up to $40 \%$ of diabetic patients will develop DN. The involvement of mesenchymal stem cells (MSCs) in diabetic renal lesions management has been established in many animal models of DN. The aim is to evaluate the capability of MSCs and their culture medium (CM) to alleviate DN in streptozotocin (STZ)-induced diabetic rat model. Female albino rats were made diabetic and were further categorized into 4 subgroups of 15 each: DN group, DN group received fibroblasts, MSCs group received one dose of $1 \times 10^{6}$ cells of MSCs, and CM group received one dose of $500 \mu \mathrm{l}$ of CM. In all groups, the treatment was delivered by intravenous injection (IV) into the tail vein.
\end{abstract}

Results: MSCs insinuated themselves into the injured kidney as detected by CD44 expression. Biochemical and histological results showed that MSCs and/or CM effectively attenuated DN manifestations in rat model through their possible anti-inflammatory (tumor necrosis factor- $\alpha$ and transforming growth factor- $\beta 1$ were decreased), antiapoptotic (Bcl2 was increased while Bax and caspases were decreased), and anti-oxidant role (malondialdehyde was decreased while glutathione and catalase were increased).

Conclusion: These results provide a potential therapeutic tool for DN management through the administration of the CM from MSCs that ameliorates the effects of diabetes. It is also possible to treat DN using CM alone thus avoiding cell transplantation.

Keywords: MSCs, Culture medium, Diabetic nephropathy, Therapeutic effect

\section{Background}

Diabetes mellitus (DM) is a worldwide public health challenge. WHO estimated that there were around 422 million people living with diabetes and that there was a rising trend in the number of people living with DM. Diabetic nephropathy (DN) is the major micro-vascular complication in diabetic patients and accounts for approximately half of all end-stage renal disease globally [1].

\footnotetext{
* Correspondence: nerminraafat@gmail.com

${ }^{4}$ Medical Biochemistry Department, Faculty of Medicine, Zagazig University, Zagazig 44512, Egypt

Full list of author information is available at the end of the article
}

The key characterized features of diabetic nephropathy include thickened basement membrane of both glomeruli and tubules, mesangial cell (MC) hypertrophy, extracellular matrix accumulation, tubule-interstitial fibrosis, and finally glomerular sclerosis which is the leading cause of micro-albuminuria and renal failure $[2,3]$. Over the last decade, many factors have been proposed to be involved in the pathogenesis of diabetic nephropathies such as genetic and hemodynamic factors, metabolic, oxidative stress, and cytokine signaling $[2,4]$.

Hyperglycemia is a discriminative pathologic element in diabetes mellitus which not only generates free radicals but also attenuates antioxidant effects via glycation 
of antioxidant enzymes [5]. The major sources of reactive oxygen species (ROS) in DN are advanced glycation end products (AGEs), autoxidation of glucose, xanthine oxidase activity, mitochondrial respiratory chain deficiencies, NADPH oxidase, and nitric oxide synthase (NOS) [6, 7]. Streptozotocin is extensively used to induce diabetes model, and its toxicity is mediated through nitric oxide $(\mathrm{NO})$ generation that affects pancreatic $\beta$-cells [8].

Currently available treatments, involving glycemic and/or blood pressure control, can delay but not abolish the development of DN [9]. Therefore, there is an imperative need to develop new, effective therapeutic strategies that preserve normal renal function or halt the progression of diabetic nephropathy.

Mesenchymal stem cells are multipotent progenitor cells which are non-hematopoietic and can differentiate into many types of cells. Stem cell therapy is considered as a new promising approach for treatment of diabetes and its complications [10]. Adipose-derived MSCs (AD-MSCs) have the capability of differentiating into cells and tissues which are of mesodermal origin. They are easily harvested and abundant which makes them an ideal choice for use [11]. MSCs have a lot of advantages for use for therapeutic purposes, such as the capability to migrate to the sites where tissue injury is present, potent immunosuppressive action $[12,13]$, and safer after infusion of allogeneic MSCs $[14,15]$.

It is reported that after the injection of MSCs, they directly infiltrate the diseased kidneys [16]. Other studies have found no evidence for direct MSCs incorporation into the kidney during the repair processes [17]. Many factors play a great role in the therapeutic action of MSCs like their ability to modulate and change local environment, activation of endogenous progenitor cells, secretion of several growth factors, and their differentiation potency to repair diseased tissue $[18,19]$.

Vascular endothelial growth factor-a (VEGF-A) is a protein secreted by podocytes that is necessary for the survival of endothelial cells, podocytes, and mesangial cells. Human kidney biopsies showed high VEGF-A mRNA at early stages of DN, and lower VEGF-A expression in advanced DN, specifically in sclerotic glomeruli and mesangial nodules [20,21]. The decline in VEGF-A expression as overt DN progresses is thought to be due to podocyte dropout $[22,23]$.

Based on the previously mentioned findings, we, therefore, raised the hypothesis that cytotherapy by the use of MSCs transplantation is of benefit in reducing diabetic nephropathy. Accordingly, this study was undertaken to evaluate the capability of MSCs to alleviate DN in streptozotocin (STZ)-induced diabetic rat model, to investigate the mechanisms underlying the protective effect of
MSCs in DN and to mark the signals of paracrine origin that mediate the action of MSCs.

\section{Methods \\ Animals and ethics}

Seventy-five healthy female albino rats (6 8 weeks) weighing $150-200 \mathrm{~g}$ and ten male albino rats (6 weeks) weighing $120-140 \mathrm{~g}$ were included in this study. They were obtained from the animal facility house of the faculty, and they were housed in a light and temperature controlled room with free access to water and food. All experimental procedures were done according to guidelines of the Institutional Review Board (IRB) for research studies (reference number is 4920/14-7-2016) and IACUC (approval number is ZU-IACUC/3/F/90/2018) for animal research.

\section{STZ-induction of diabetic nephropathy in rats}

To establish type 1 diabetic rat model, $50 \mathrm{mg} / \mathrm{kg}$ body weight of STZ (Sigma, St Louis, USA) was dissolved in $0.05 \mathrm{ml}$ saline and injected intraperitoneal into adult rats twice 4 days apart. Diabetes was defined when a random rat blood glucose level reading of more than $300 \mathrm{mg} / \mathrm{dl}$ in the 3 continuous days at day 14 after STZ injection was done [24]. Diabetic nephropathy was confirmed 4 weeks after onset of diabetes mellitus by measuring serum urea and creatinine in blood and also by histopathological changes scarifying one rat every 2 weeks [25].

\section{Experimental design}

The animals were allocated into the following groups, control group which received phosphate buffered saline (PBS) at time of injection, included 15 female albino rats, and diabetic nephropathy group, comprised 60 female albino rats that were further categorized into 4 subgroups of 15 each: DN group, fibroblast group received one dose of $1 \times 10^{6} \mathrm{HFF}-1$ cells (a human fibroblast cell line from American Type Culture Collection (ATCC)) were used as the negative control for migrating cells according to Domouky et al. [24], MSCs group received one dose of $1 \times 10^{6}$ cells of MSCs per rat, and CM group received one dose of $500 \mu \mathrm{l}$ of culture medium (MSCs were cultured with Dulbecco's Modified Eagle's Medium (DMEM) for $24 \mathrm{~h}$. In all groups, the treatment was delivered by intravenous injection (IV) into the tail vein.

\section{Preparation of adipose tissue-derived mesenchymal stem cells (AT-MSCs) Isolation of AD-MSCs from male rats}

AT-MSCs were isolated from the peritoneal adipose tissue excised from the abdominal region of 6 8week-old male albino rats. Adipose tissue was 
enzymatically digested with $0.075 \%$ collagenase (type I; Sigma-Aldrich, St. Louis, MO) in PBS for $1 \mathrm{~h}$ at $37{ }^{\circ} \mathrm{C}$ with gentle agitation. The collagenase was inactivated with an equal volume of DMEM (GIBCO/BRL) supplemented with $10 \%$ fetal bovine serum (FBS), and the infranatant was centrifuged at $1000 \times g$ for $5 \mathrm{~min}$ at room temperature. The resulting cell pellet was resuspended in $160 \mathrm{mM} \mathrm{NH4Cl}$ (Stem Cell Technologies Inc., Vancouver, BC), incubated at room temperature for $2 \mathrm{~min}$ to eliminate contaminating red blood cells, and filtered through a $100-\mu \mathrm{m}$ nylon mesh strainer (Becton Dickinson Labware, Franklin Lakes, NJ) to remove debris [26]. The culture of isolated cells was done according to Raafat et al. [27].

For the conditioned medium-treated groups, the MSCs were cultured in DMEM without FBS for $24 \mathrm{~h}$. After this period, the medium was collected, centrifuged, and filtered to remove the cells, treated with an RNase inhibitor $(500 \mathrm{U})$ and administered to the rats [28].

\section{Characterization of AD-derived MSCs}

MSCs at day 14 are characterized by their adhesiveness and fusiform, star, or spindle shape. MSCs by flow cytometric evaluation express CD105, CD73, and CD29 on their cell surface, and they do not express CD34, CD45, or MHC-class II.

\section{Blood and tissue sampling}

After 12 weeks of STZ injection according to Fang et al. [25], animals were fasted for half a day, and blood samples were obtained by puncturing retro-orbital plexus under light ether anesthesia. All rats were then sacrificed by cervical dislocation, and tissue was perfused with PBS solution, containing $0.16 \mathrm{mg} / \mathrm{ml}$ heparin to remove any red blood corpuscles and clots. Both kidneys were immediately excised, dried, and weighed. The parts of the kidney were kept in $10 \%$ formalin for the histological assessment and immune-histochemistry, and then the kidneys were minced into small parts for different parameters assessment. The blood samples were left for 30-60 min for spontaneous clotting. Serum samples were separated for assessment of urea and creatinine.

\section{PCR detection of the Sry gene}

Genomic DNA was extracted from the kidney tissue using the QIAamp DNA purification kit (QIAGEN, Germany). PCR analysis for Sry gene expression in ADMSCs recipient rats was done using primer sequence listed in Table 1 [29]. The amplification protocol was as follows: $95^{\circ} \mathrm{C}$ for $5 \mathrm{~min}$; then 35 cycles of $95{ }^{\circ} \mathrm{C}$ for $35 \mathrm{~s}$, $50{ }^{\circ} \mathrm{C}$ for $60 \mathrm{~s}$, and $72{ }^{\circ} \mathrm{C}$ for $60 \mathrm{~s}$; then $72{ }^{\circ} \mathrm{C}$ for $5 \mathrm{~min}$, using heated lid thermal cycler (Mastercycler ${ }^{\circ}$ pro, Eppindorf, Germany).

\section{Reverse transcription PCR for renal localization of MSC}

Total RNA was isolated from the renal tissue with QiagenRNeasy Mini kit. RNA was reverse-transcribed to cDNA using a Primescript RT Reagent Kit (Takara, Shiga, Japan). The primers sequences used for CD105 and CD34 are listed in Table 1. PCR was performed for 35 cycles with each cycle comprising $20 \mathrm{~s}$ at $94{ }^{\circ} \mathrm{C}, 30 \mathrm{~s}$ at $55{ }^{\circ} \mathrm{C}$ for $\mathrm{CD} 105$ and $60{ }^{\circ} \mathrm{C}$ for $\mathrm{CD} 34$ and $\beta$-actin, and $1 \mathrm{~min}$ at $72{ }^{\circ} \mathrm{C}[30]$.

\section{Biochemical analysis}

\section{Kidney function assessment}

Urea level was estimated in accordance to Fawcett and Scott's method (1960) [31], and serum creatinine level was measured in accordance to Henry's method (1974)

Table 1 Primers sequence of Sry, CD105, CD34, Bax, bcl2, caspase-3, caspase-8, and $\beta$-actin genes

\begin{tabular}{|c|c|c|c|}
\hline Target & Ref seq accession & Sequence & Product size (bp) \\
\hline Sry & NM_012772 & $\begin{array}{l}\text { F: 5'-TGGGACTGGTGACAATTGTC-3' } \\
\text { R: 5'-GAGTACAGGTGTGCAGCTCT-3' }\end{array}$ & 402 \\
\hline CD105 & NM_007932 & $\begin{array}{l}\text { F: 5'-AGACAGCTGCCATCTGGATTT-3' } \\
\text { R: 5'-GGGCACGTGTGTGAGAATAGA-3' }\end{array}$ & 374 \\
\hline CD34 & NM_133654 & $\begin{array}{l}\text { F: 5'-GCGTGAGAATGCCGGTCCA-3' } \\
\text { R: 5'-TCAGCAAACACTCGGGCCTAA-3' }\end{array}$ & 744 \\
\hline Bax & NM_017059.2 & $\begin{array}{l}\text { F: 5'-GGCGAATTGGAGATGAACTG-3' } \\
\text { R: 5'-TGCCATCAGCAAACATGTCA-3' }\end{array}$ & 120 \\
\hline $\mathrm{Bcl}-2$ & NM_016993.1 & $\begin{array}{l}\text { F: 5'-ATCCAGGATAACGGAGGCTG-3' } \\
\text { R: 5'-CAGGTATGCACCCAGAGTGA -3' }\end{array}$ & 144 \\
\hline Caspase-3 & NM_012922.2 & $\begin{array}{l}\text { F: 5'-AATTCAAGGGACGGGTCATG-3' } \\
\text { R: 5'-TGACACAATACACGGGATCTG-3' }\end{array}$ & 180 \\
\hline Caspase-8 & NM_022277.1 & $\begin{array}{l}\text { F: 5'-GATGAGGCAGACTTTCTGCT-3' } \\
\text { R: 5'-CATAGTTCACGCCAGTCAGGAT-3' }\end{array}$ & 163 \\
\hline$\beta$-actin & NM_031144.3 & $\begin{array}{l}\text { F: 5'-AGGGAAATCGTGCGTGACAT-3' } \\
\text { R: 5'-GAACCGCTCATTGCCGATAG-3' }\end{array}$ & 150 \\
\hline
\end{tabular}


[32] by using reagent kit obtained from the Diagnostics Company (Egypt).

\section{Renal oxidant-antioxidant markers assessment}

Malondialdehyde (MDA) [33], reduced glutathione (GSH) [34], and catalase (CAT) [35] on renal tissues were assessed in accordance to the respective manufacturer's instructions (Biodiagnostic Tahreer St., Dokki, Giza, Egypt).

\section{Measurement of tumor necrosis factor- $\alpha$ (TNF- $\alpha$ ) and transforming growth factor- $\beta 1$ (TGF- $\beta 1$ )}

The content of protein in kidney homogenates (Vertishear tissue homogenizer) was determined by Bradford's method (1976) [36] by using crystalline BSA as standard. The TNF- $\alpha$ and TGF- $\beta 1$ levels were quantified by quantitative enzyme-linked immunosorbent assay (ELISA) kits according to the manufacturer's instructions (TNF- $\alpha$ rat ELISA kit, ab100785 and TGF- $\beta 1$ rat ELISA kits, ab119558, Abcam, UK). Results are mentioned as picogram per milligram protein.

\section{Quantitative real-time PCR (qRT-PCR) for apoptotic markers gene expression}

Expression levels in cDNA were determined by Stratagene, MX3000P quantitative PCR System (Agilent Technologies) and analyzed using the MxPro QPCR Software (Agilent technologies). Table 1 lists the primer sequences used for Bax, Bcl2, caspase-3, 8, and $\beta$-actin [37, 38].

The PCR was performed on $25 \mu \mathrm{l}$ containing $12.5 \mu \mathrm{l}$ $2 \times$ QuantiFast SYBR Green PCR Master Mix, $1 \mu \mathrm{M}$ of each primer, and $5 \mu \mathrm{l} \mathrm{cDNA}$ with the following conditions: $95{ }^{\circ} \mathrm{C}$ for $5 \mathrm{~min}$, then 40 cycles at $95{ }^{\circ} \mathrm{C}$ for $10 \mathrm{~s}$, and combined annealing and extension $60{ }^{\circ} \mathrm{C}$ for $30 \mathrm{~s}$. All kits were supplied by (QIAGEN, Valencia, CA, USA). Samples were assessed in duplicates to make sure the reproducibility and accuracy of the obtained results.

\section{Histological and immunohistochemical analysis}

The kidneys were dissected, washed with phosphate buffer saline, and fixed in 10\% formalin solution. Tissue samples were dehydrated in gradual grades of alcohol, cleared in xylolthen embedded in paraffin sections. Five micrometer thickness sections were obtained via using a microtome, mounted on slides, and subjected to hematoxylin and eosin stain (H\&E) [39], periodic acid Schiff reaction (PAS) counterstained with hematoxylin [40], Mallory's trichrome stain [41], immunohistochemical staining for detection of CD44 antigen using rat monoclonal anti CD44 antibody "Neomarkers, Labvision, USA," as a marker for mesenchymal stem cells [42], and immunohistochemical staining for VEGF [43].

The avidin-biotin-peroxidase complex technique was done as follows for immunohistochemical detection of
CD44 and VEGF; paraffin sections were deparaffinized and rehydrated. The endogenous activity of peroxidase was blocked by $3 \%$ solution of hydrogen peroxide for 5 min. Then, the kidney sections were incubated for 30 min with primary antibody. The primary antibody used was a monoclonal anti-CD44 (Lab Vision Corporation, Thurmont, California, USA) and monoclonal antibody for detection of VEGF (anti- VEGF, Lab Vision, USA). The secondary antibody (biotinylated goat anti-rabbit) was applied after washing the sections with phosphate buffer. The slides were rinsed in PBS then incubated with labelled avidin-biotin peroxidase. Avidin-biotinperoxidase complex (Histostain SP kit, Zymed Laboratories Inc, San Francisco, USA) is used for immunedetection of the bound primary antibody. The binding site was visualized after adding diaminobenzidine (DAB) which was used as a chromogen, which is converted into a brown precipitate and Meyer's hematoxylin as a counterstain.

\section{Quantitative morphometric study}

Morphometric measurements were performed via using Leica Q500 Imaging analysis System. The following parameters were measured: urinary space diameter (USD) $(\mu \mathrm{m})$ which is the distance between visceral and parietal layer of the glomerulus, outer diameter of the proximal convoluted tubules (PCD) $(\mu \mathrm{m})$, outer diameter of the distal convoluted tubule (DCD) $(\mu \mathrm{m})$, and the area percent (AP) $\left(\mu \mathrm{m}^{2}\right)$ occupied by collagen fibers within the glomeruli and around the tubules. Measurements of USD, PCD, and DCD were assessed in PAS-stained slides while AP was calculated in Mallory stained sections. All parameter measurements were detected in magnification of $\times 400$ for 25 randomly selected glomeruli, proximal, and distal convoluted tubules in each animal.

\section{Statistical analysis}

The results for quantitative variables are mentioned as mean \pm standard deviation. The means were compared in a one-way analysis of variance and multiple comparison post hoc tests. Differences between groups were considered significant when $P$ values were $<0.05$ and highly significant when $P$ values were $<0.001$. Statistical analyses were done via the use of SPSS, version 10 (SPSS Inc).

\section{Results}

\section{Characterization of AD-MSCs}

AD-MSCs were characterized by their adhesiveness and fusiform shape, spindle, and fibroblast-like cells. Flow cytometric analysis of cell surface markers on gated cells showed positive surface expression of CD29, CD73, and CD105 (PE labelled) while the mainstream of cells showed negative expression of CD34, CD45, and MHC- 
class II (FITC labelled). This surface marker expression patterns corresponded to AD-MSC in accordance with the International Society of Cellular Therapy system. The kidney sections of AD-MSC group showed a CD44 positive immunoreactive spindle-shaped cell exhibiting intense brown colored cytoplasmic granules. The positive CD44 cells are located in-between tubules or incorporated with the cells of the kidney tubules (Fig. 1).

Sry gene (402 bp) was expressed in male rats from which AD-MSCs were isolated. It was also detected in renal cells of female rats that were injected by malederived AD-MSCs in MSCs group. The Y-chromosome marker was neither detected in the control group nor in the DN group nor in the CM group. MSC-specific marker CD105 gene (374 bp) was expressed in renal tissue, but CD34 gene (744 bp) was not detected. These results indicate that our AD-MSCs were consistent with recognized MSCs.

\section{Effect of MSCs/CM on kidney function tests}

Treatment with MSCs/CM showed a significant decrease in serum creatinine and urea levels $(P<0.01$ and $P<$ 0.05 , respectively) as compared to DN rats or fibroblast injected rats. Table 2 shows the kidney function tests in the studied groups.

\section{Effect of MSCs/CM on markers of oxidative stress in renal} tissue

MDA was significantly $(P<0.001)$ increased in renal tissue of diabetic nephropathy rats as compared to nondiabetic rats. There was a highly significant $(P<0.001)$ decrease in the levels of GSH and CAT in renal tissue as

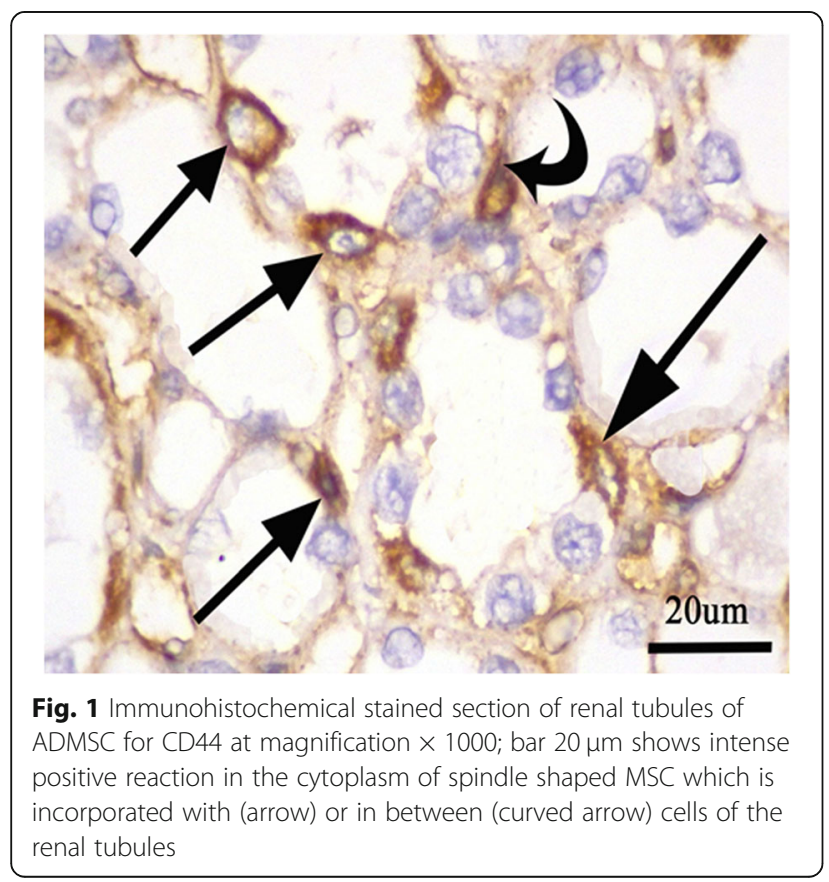

Table 2 Kidney functions assessment in the different studied rats' groups

\begin{tabular}{lll}
\hline $\begin{array}{l}\text { Studied groups } \\
\text { (number of rats) }\end{array}$ & Kidney function tests \\
\cline { 2 - 3 } & Serum creatinine $(\mathrm{mg} / \mathrm{dl})$ & Serum urea(mg/dl) \\
\hline Control $(n=15)$ & $0.63 \pm 0.08$ & $24.66 \pm 2.86$ \\
DN $(n=15)$ & $2.17 \pm 0.32^{\mathrm{a}}$ & $56.84 \pm 4.68^{\mathrm{a}}$ \\
Fibroblast $(n=15)$ & $2.2 \pm 0.23^{\mathrm{a}}$ & $60.13 \pm 0.9^{\mathrm{a}}$ \\
AD-MSC $(n=15)$ & $1.05 \pm 0.04^{\mathrm{b}, \mathrm{c}}$ & $38.40 \pm 1.09^{\mathrm{b}, \mathrm{c}}$ \\
CM $(n=15)$ & $1.00 \pm 0.02^{\mathrm{b}, \mathrm{c}}$ & $35.23 \pm 1.02^{\mathrm{b}, \mathrm{c}, \mathrm{d}}$ \\
$F$ & 241.42 & 511.12 \\
$P$ & $<0.001$ & $P<0.001$ \\
\hline
\end{tabular}

One-way ANOVA, post hoc tests, $P>0.05$ no significant differences, $P<0.05$ significant differences, and $P<0.001$ highly significant differences

${ }^{a}$ Significant difference vs control group

${ }^{\mathrm{b}}$ Significant difference vs DN group

'Significant difference vs fibroblast group

${ }^{\mathrm{d}}$ Significant difference vs AD-MSC group

compared to normal control group. MSC/CM treatment of diabetic nephropathy rats showed a significant decrease $(P<0.01)$ in MDA levels and a significant increase in GSH and CAT $(P<0.05$ and $P<0.01$, respectively) as compared to $\mathrm{DN}$ or fibroblast injected rats (Table 3).

\section{Effect of MSCs/CM on TNF- $\alpha$ and TGF- $\beta$ levels in renal tissue}

Diabetic nephropathy and fibroblast injected groups showed a highly significant $(P<0.001)$ increase in inflammatory markers such as renal TNF- $\alpha$ and TGF- $\beta$ levels as compared to normal control rats' kidneys. MSC/CM treated rats showed a significant reduction in TNF- $\alpha(P<0.001)$ level and TGF- $\beta(P<0.01)$ (Table 4$)$. There was an insignificant difference between MSCs and $\mathrm{CM}$ group indicating that the action is paracrine.

\section{Effect of MSCs/CM on apoptotic and anti-apoptotic markers in renal tissue}

Bcl2 gene expression was significantly decreased while Bax, caspase-3, and caspase- 8 were significantly increased in the DN or fibroblast groups as compared to the control group $(P<0.001)$. Administration of either MSCs or CM to DN rats has a reversed response as there was highly significant increase in $\mathrm{Bcl} 2$ gene expression and decreased Bax, caspase- 3 , and caspase- 8 gene expression $(P<0.001)$. There was also non-significant difference in those genes expression between MSCs/CM and control group (Fig. 2).

\section{Histological and immunohistochemical results Hematoxylin and eosin staining findings}

H\&E stained sections of the control group showed normal glomeruli lined with visceral and parietal cells with normal Bowman's space in between. The tubules, 
Table 3 Oxidative stress markers in the different studied rats' groups

\begin{tabular}{llll}
\hline Studied groups & \multicolumn{2}{l}{ Oxidative stress markers } & CAT (U/g tissue) \\
\cline { 2 - 4 } & MDA (nmol/g tissue) & GSH (mg/g tissue) & $8.62 \pm 0.76$ \\
\hline Control $(n=15)$ & $45.13 \pm 7.24$ & $95.87 \pm 2.13$ & $5.83 \pm 0.82^{\mathrm{a}}$ \\
DN $(n=15)$ & $105.32 \pm 6.1^{\mathrm{a}}$ & $75.81 \pm 2.09^{\mathrm{a}}$ & $4.3 \pm 0.09^{\mathrm{a}, \mathrm{b}}$ \\
Fibroblast $(n=15)$ & $102.42 \pm 1.3^{\mathrm{a}}$ & $77.17 \pm 1.22^{\mathrm{a}}$ & $7.86 \pm 0.45^{\mathrm{b}, \mathrm{c}}$ \\
AD-MSC $(n=15)$ & $63.31 \pm 6.45^{\mathrm{a}, \mathrm{b}, \mathrm{c}}$ & $84.89 \pm 1.72^{\mathrm{b}, \mathrm{c}}$ & $6.90 \pm 0.35^{\mathrm{b}, \mathrm{c}, \mathrm{d}}$ \\
CM $(n=15)$ & $60.45 \pm 4.15^{\mathrm{a}, \mathrm{b}, \mathrm{c}}$ & $82.06 \pm 2.52^{\mathrm{b}, \mathrm{c}}$ & 197.49 \\
$F$ & 572.97 & 355.06 & $<0.001$ \\
$P$ & $<0.001$ & $<0.001$ & $<$
\end{tabular}

One-way ANOVA, post hoc tests, $P>0.05$ no significant differences, $P<0.05$ significant differences, and $P<0.001$ highly significant differences

$M D A$ malondialdehyde, GSH reduced glutathione, $C A T$ catalase

${ }^{a}$ Significant difference vs control group

bSignificant difference vs DN group

'Significant difference vs fibroblast group

${ }^{\mathrm{d}}$ Significant difference vs AD-MSC group

proximal convoluted tubules (PCT) and distal convoluted tubules (DCT), showed normal histological appearance (Fig. 3a). H\&E stained sections of the diabetic group showed that the glomeruli appeared to be distorted with expanded Bowman's space; some of the glomeruli showed foci of hyalinosis and eosinophilic deposits (Fig. 3b). Tubular atrophy with flattening of epithelial cells, broken membranes, and loss of brush border was observed in PCT also; DCT showed disorganization and atrophy with dilated lumina (Fig. 3c). Blood vessels showed marked thickening (hyalinization) with lymphocytic infiltration (Fig. 3d). H\&E stained sections of fibroblast group exhibited shrunken distorted glomeruli. The tubules had vacuolated cytoplasm and darkly stained nuclei. Blood vessels showed thickening (hyalinization) (Fig. 3e). H\&E stained sections of MScs (Fig. 3f) or CM (Fig. 3g) administration to DN rats revealed marked improvement of renal architecture when

Table 4 TNF- $\alpha$ and TGF- $\beta$ assessment in the different studied rats' groups

\begin{tabular}{lll}
\hline Studied groups & Inflammatory markers & \\
\cline { 2 - 3 } & TGF- $\beta 1(\mathrm{pg} / \mathrm{mg}$ protein $)$ & TNF-a $(\mathrm{pg} / \mathrm{mg}$ protein $)$ \\
\hline Control $(n=15)$ & $80.63 \pm 10.42$ & $18.09 \pm 0.86$ \\
DN $(n=15)$ & $206.17 \pm 22.30^{\mathrm{a}}$ & $43.14 \pm 1.13^{\mathrm{a}}$ \\
Fibroblast $(n=15)$ & $210.12 \pm 11.32^{\mathrm{a}}$ & $40.22 \pm 1.33^{\mathrm{a}}$ \\
AD-MSC $(n=15)$ & $101.05 \pm 6.04^{\mathrm{b}, \mathrm{c}}$ & $25.40 \pm 0.29^{\mathrm{b}, \mathrm{c}}$ \\
CM $(n=15)$ & $98.15 \pm 5.24^{\mathrm{b}, \mathrm{c}}$ & $23.92 \pm 0.17^{\mathrm{b}, \mathrm{c}}$ \\
$F$ & 591.81 & 2132.72 \\
$P$ & $<0.001$ & $<0.001$
\end{tabular}

One-way ANOVA, post hoc tests, $P>0.05$ no significant differences, $P<0.05$ significant differences, and $P<0.001$ highly significant differences

TNF- $a$ tumor necrosis factor alpha, TGF- $\beta$ transforming growth factor beta 1

aSignificant difference vs control group

${ }^{\mathrm{b}}$ Significant difference vs DN group

'Significant difference vs fibroblast group compared to the DN group or fibroblast group. The glomeruli and tubules appeared nearly similar to normal control group except that there were minimal focal tubular lesions which involve few tubules

\section{Mallory staining findings}

Examination of renal cortex sections from control group showed thin blue collagen fibers around renal glomeruli and tubules (Fig. 4a) while DN group (Fig. 4b) or fibroblast group (Fig. 4c) revealed excess blue stained collagen fibers around tubules and around and within the glomeruli, and foci of interstitial fibrosis were noticed. Sections of MScs or CM administration to DN rats demonstrated thin blue collagen fibers around renal glomeruli and tubules (Fig. 4d, e).

\section{Periodic acid Schiff reaction (PAS) staining findings}

The control group showed a positive reaction for PAS in the form of the thin basement membrane of Bowman's capsule and thin tubular basement membrane. Also, a positive reaction was observed in the luminal brush border of PCT (Fig. 5a). The kidney tissue of diabetic group (DN) (Fig. 5b) or fibroblast group (Fig. 5c) showed a thick basement membrane of Bowman's capsule and diffuse thickening of the tubular basement membrane. Loss of brush border of PCT was also noted. By PASstained sections of MScs or CM administration to DN rats revealed improvement in the form of the relatively thin basement membrane of the Bowman's capsule and the tubules. Most of PCT retained their brush border (Fig. 5d, e)

\section{The immunohistochemical reaction for VEGF}

The control group showed a strong positive reaction for vascular endothelial growth factor (VEGF) expression in glomeruli and tubules (Fig. 6a). In the diabetic group (Fig. 6b) or fibroblast group (Fig. 6c), faint or no reaction 


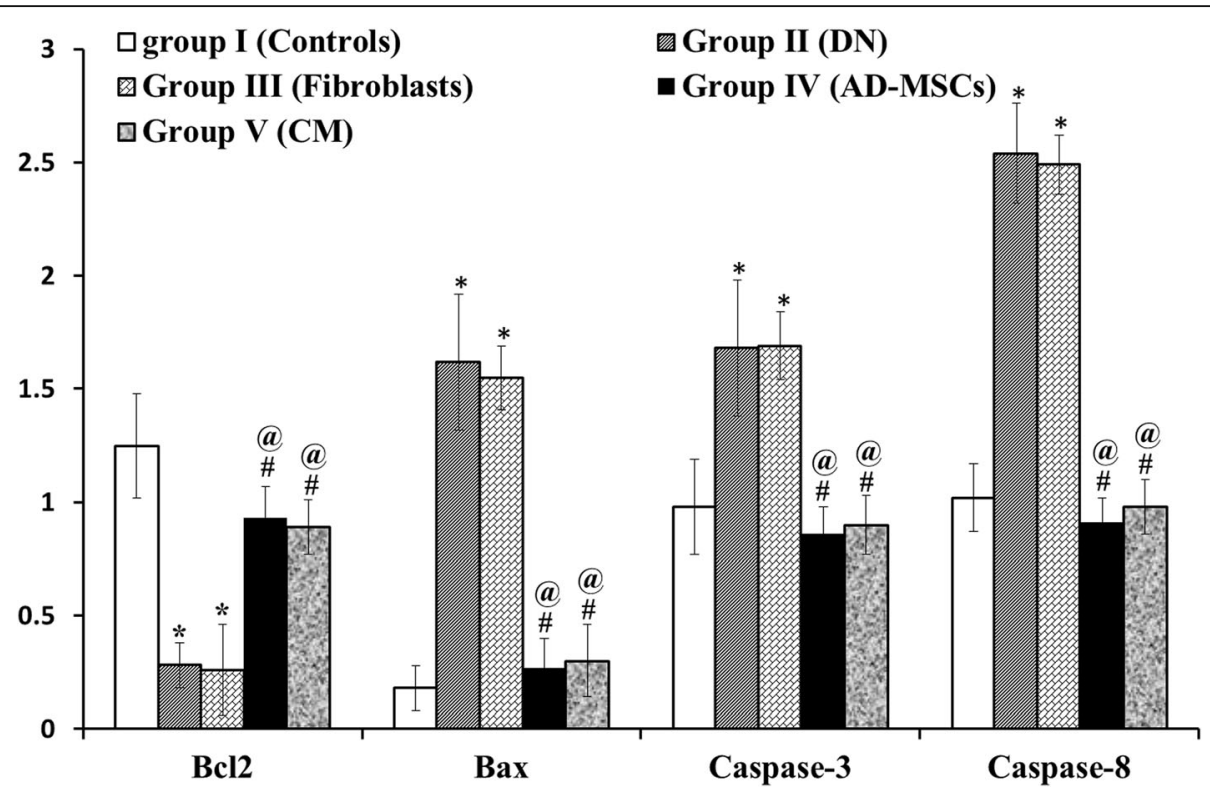

Fig. 2 mRNA gene expression of $B c \mid 2$, Bax, caspase-3, and caspase-8 when normalized to $\beta$-actin gene in group I (control), group II (DN), group III (fibroblast), group IV (AD-MSCs treated), and group V (CM). Asterisk (*) indicates high significant difference vs control group, number sign (\#) indicates high significant difference vs DN group, and commercial at (@) indicates high significant difference vs fibroblast group $(P$ value $<0.001)$

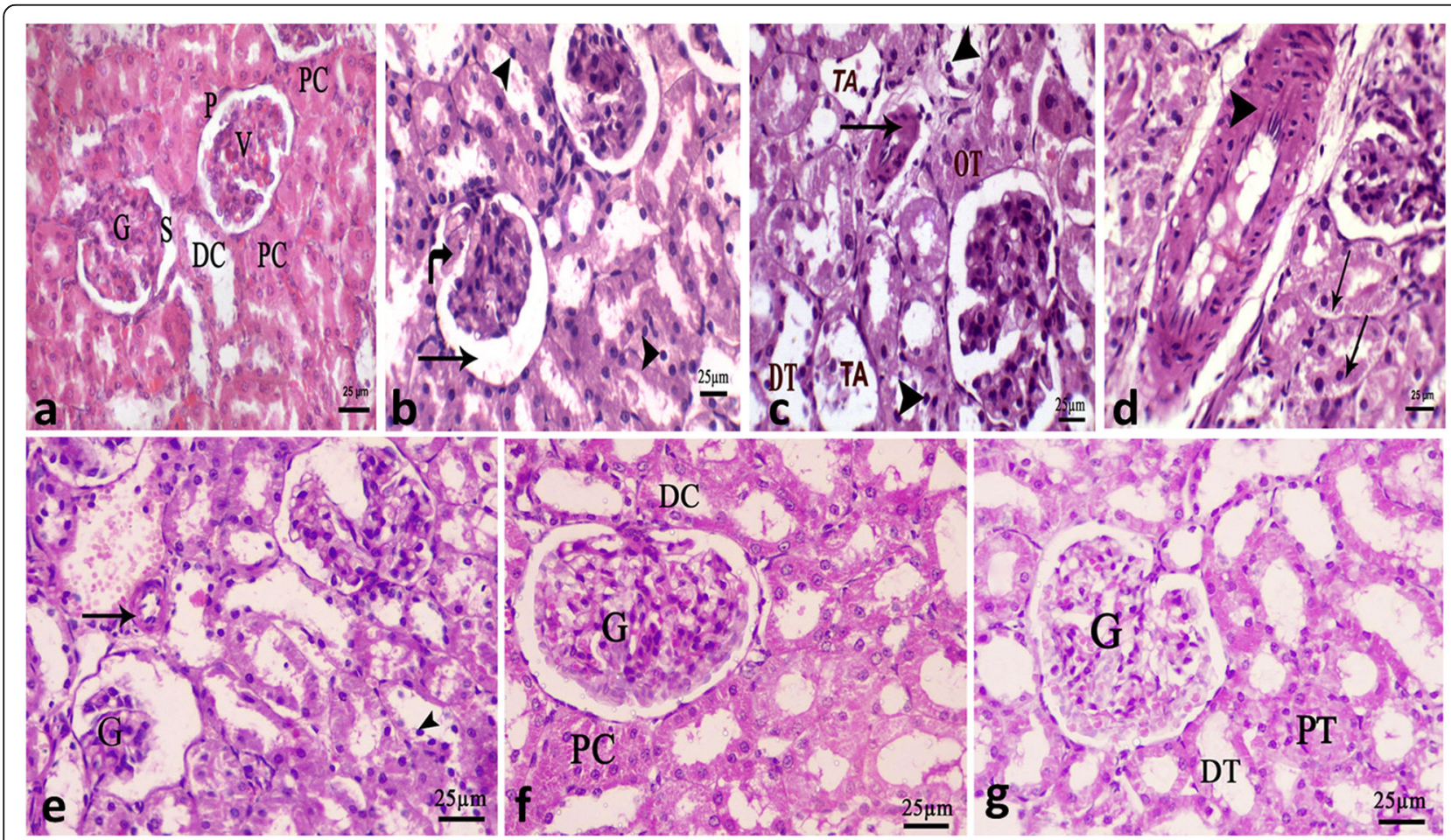

Fig. 3 H\&E stained renal cortex sections at magnification $\times 400$, bar $25 \mu \mathrm{m}$. a Control group shows normal structure of glomeruli (G) with Bowman's spaces $(S)$ which is lined by visceral $(V)$ and parietal $(P)$ cells. Proximal tubules $(P C)$ and distal tubules $(D C)$ are also showed. b-d Renal cortex of diabetic nephropathy group (b) has distorted glomeruli with expanded Bowman space (arrow). The glomeruli showed foci of hyalinosis and eosinophilic deposits (curved arrow) while tubules show dark stained nuclei (arrows heads). c Some tubules are atrophied (TA); others are dilated (DT), and some are obliterated (OT). d Blood vessels have marked hyalinization (arrow head). Dark nuclei and a vacuolated cytoplasm (arrow) are seen within tubules. e Fibroblast group shows distorted shrunken glomeruli (G); blood vessels showed hyalinosis (arrow), and tubules show dark stained nuclei (arrow head). f ADMSC group shows marked improvement in the glomeruli (G), proximal tubules (PT), and distal tubules (DT). $\mathbf{g}$ Culture media group shows the glomeruli (G), proximal tubules (PC), and distal tubules (DC) appear nearly similar to that of the control 


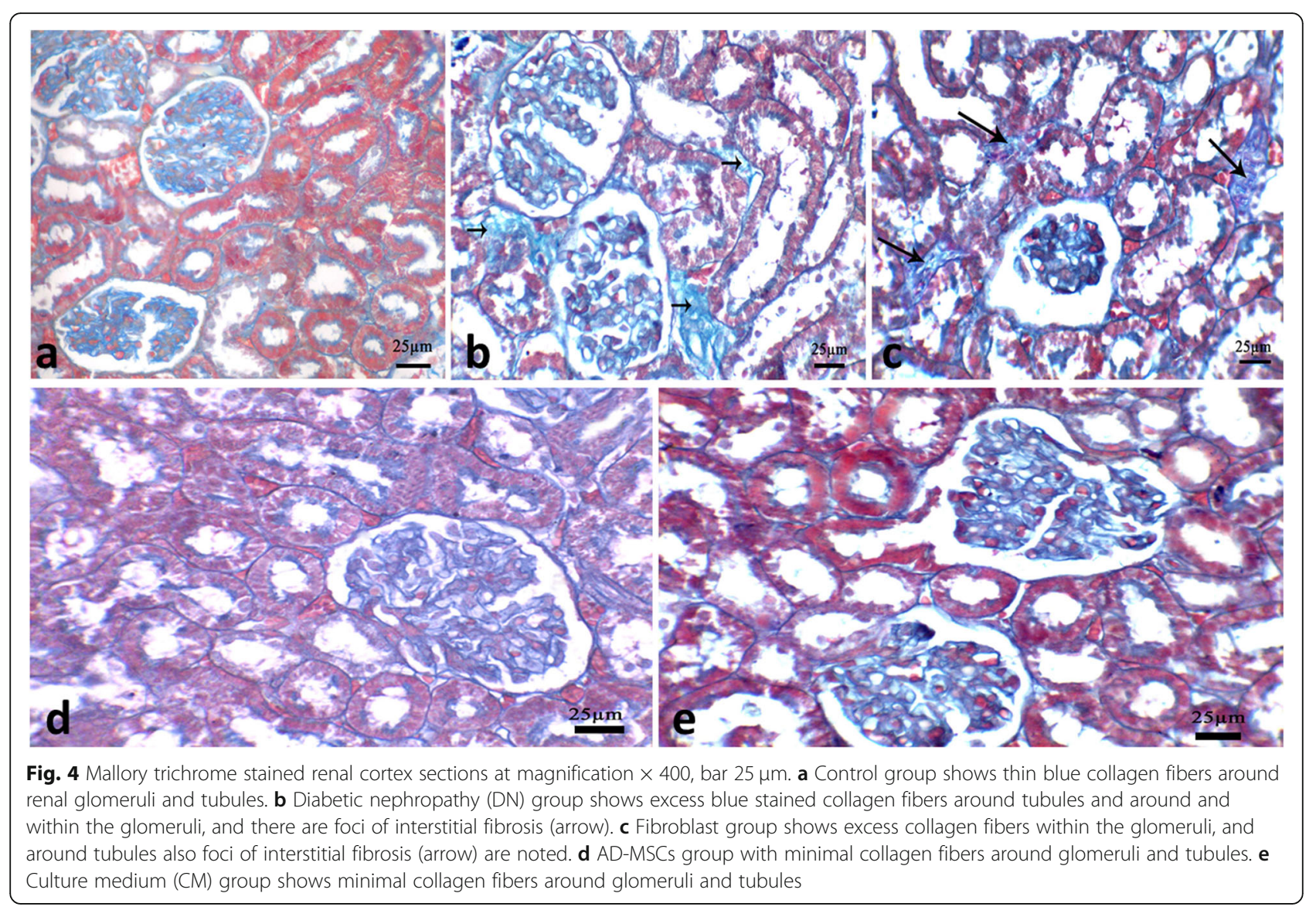

for vascular endothelial growth factor (VEGF) expression in glomeruli and tubules was found. The MSC or CM administration to $\mathrm{DN}$ rats revealed a positive reaction for VEGF expression in glomeruli and tubules (Fig. 6d, e).

\section{Morphometric results}

The USD, DCD, and AP were highly significantly increased in DN and fibroblast groups compared to the control group $(P<0.001)$. Administration of ADMSCs or $\mathrm{CM}$ to $\mathrm{DN}$ rats showed highly significant decrease in the USD, PCD, and DCD $(P<0.001)$. No significant statistical difference was found between ADMSCs or $\mathrm{CM}$ groups and control group $(P>0.05)$ (Table 5). As regards the PCD, there was a significant increase in DN and fibroblast as compared with that of control $(P<$ 0.05). In ADMSC or CM groups, there was a significant decrease in the PCD compared to DN or fibroblast groups $(P<0.05)$; however, no significant difference was found between ADMSC and CM groups $(P>0.05)$.

\section{Discussion}

Diabetic nephropathy represents one of the serious complications of diabetes mellitus [44]. There was no uncertainty that MSCs played an active role in the treatment of DN. As the nephrons have a mesenchymal origin, so MSCs are considered as suitable and striking candidates which motivate repair of renal tissue. The stromal connective cells are capable of signaling with differentiation into collecting ducts and nephrons [45]. In this study, MSCs were used to determine their possible antiinflammatory, anti-apoptotic, and anti-oxidant role in amelioration of renal function in the DN model. Fibroblast cell line was used as the negative control for migration of MSCs. MSC and fibroblast share similar morphology and cell surface markers, so we had to be sure that the therapeutic effects of MSC are due to its unique characteristics and not due to its similarity in some features to fibroblasts, so we gave fibroblasts injection to a DN group. MSCs were actually insinuating themselves into the injured kidneys as detected by CD44 expression in the kidney tissue by immunohistochemistry. Similar finding has been registered by Morigi et al., who reported homing of mice MSCs in the injured kidney [16].

The kidney of DN group showed expanded Bowman's space and deposition of eosinophilic material plus distorted glomeruli with hyalinosis. These changes go hand in hand with Najafian et al. who reported that the earliest sign in $\mathrm{DN}$ is microalbuminuria which occurred with 


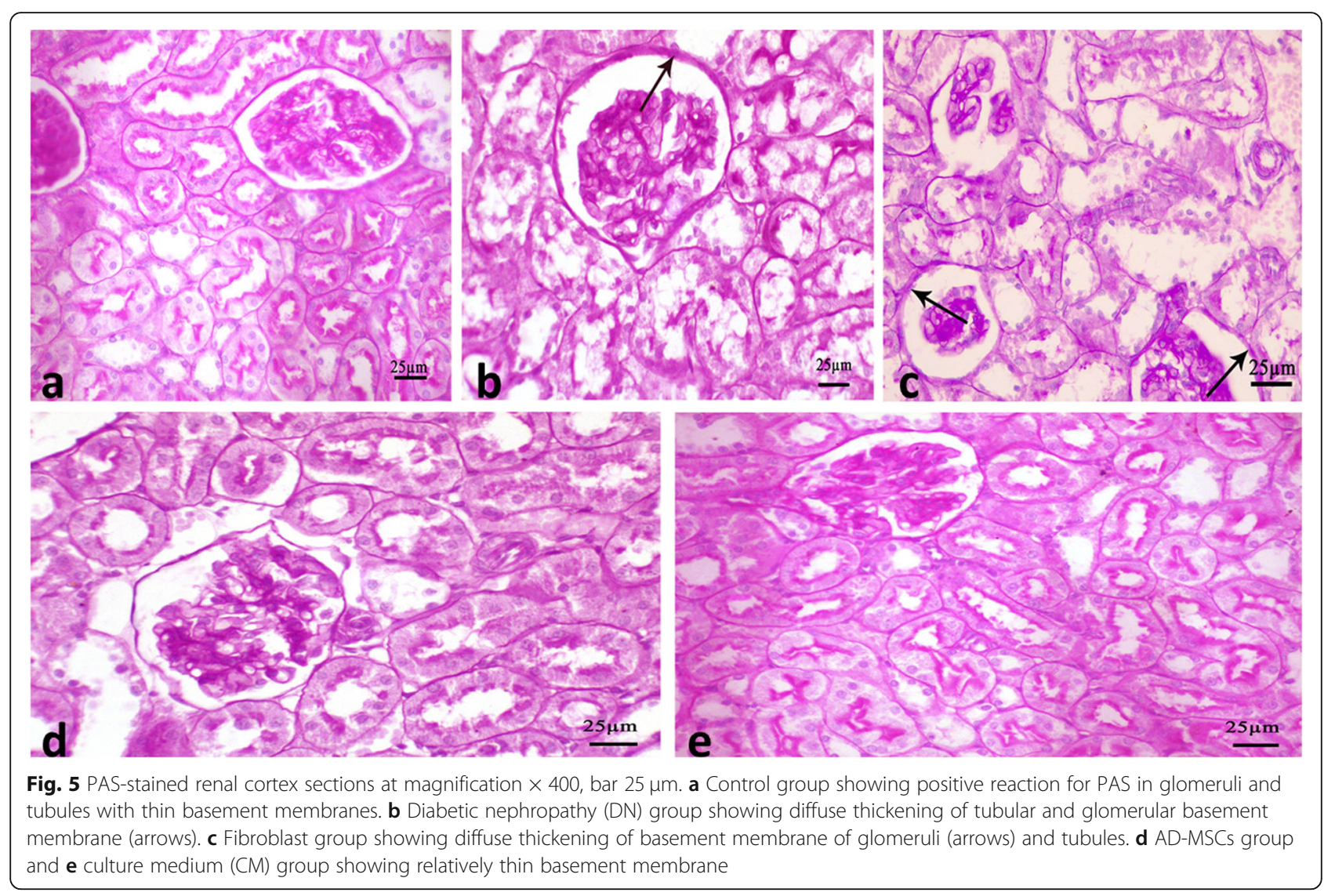

histological changes such as deposition of extracellular matrix and glomerular basement membrane thickening [46]. Also, Raparia et al. stated that the characteristic structural changes in DN, including thickening of glomerular basement membrane, hypertrophy, and proliferation of the mesangial cell [47]. Tubules in the same group DN group showed atrophy, broken membranes, and loss of brush border of PCT. The above results are in accordance with Kim et al. [48] and Zafar et al. [49].

In the current study, the $\mathrm{DN}$ rat injected with fibroblast showed similar biochemical, histological, and morphometric results to DN group. These results support that fibroblast had no effect in improvement of diabetic nephropathy. Histological examination of the DN group after stem cell injection revealed that the histology of renal corpuscles retained partially the normal appearance of the control group. This result is in concomitant with Wong et al. who stated that MSCs can regenerate, differentiate, and/or protect mesangial cells [50]. Also, the tubules retain normal structure, and this is in agreement with Qian et al. [51] and Wu et al. [52] who demonstrated the ability MSC differentiation into tubular cells. So, MSCs have been described and considered as being renotropic $[16,53]$, and Lv et al. revealed that the reno-protective effect of MSCs is through reduction of inflammation and fibrosis [54].
Fifty percent replacement of proximal tubular cells with donor cells was observed by Ling et al. [55]. Rookmaaker et al. declared that BM-MSCs participate in regeneration of the highly specialized glomerular microvasculature by homing to injured glomerular endothelium and differentiate into endothelial cells [56]. They confirmed previous observations that BM-MSCs can replace injured mesangial cells [57] and injured glomeruli [19].

The morphometric analysis of this study exhibited statistically significant differences of USD, PCD, DCD, and AP between DN or fibroblast groups to control group. However, DN rats treated with ADMSC or CM showed a significant reduction in all these parameters compared to DN and fibroblast groups. Administration of ADMSC or $\mathrm{CM}$ to $\mathrm{DN}$ rats assisted in restoring the morphometric parameters to normal levels. Morphometric results are parallel to histopathological results.

The histological and biochemical results of the $\mathrm{CM}$ group showed similar results to the MSCs group. CM enhanced the recovery of renal function in DN, suggesting that MSCs participate in a regenerative cytokine environment. It could be hypothesized that the mechanisms that mediate the defensive effects of MSCs could be paracrine [58]. These results provide a rationale for the potential therapeutic tool for DN treatment because the effects of the administration of the CM from MSCs 


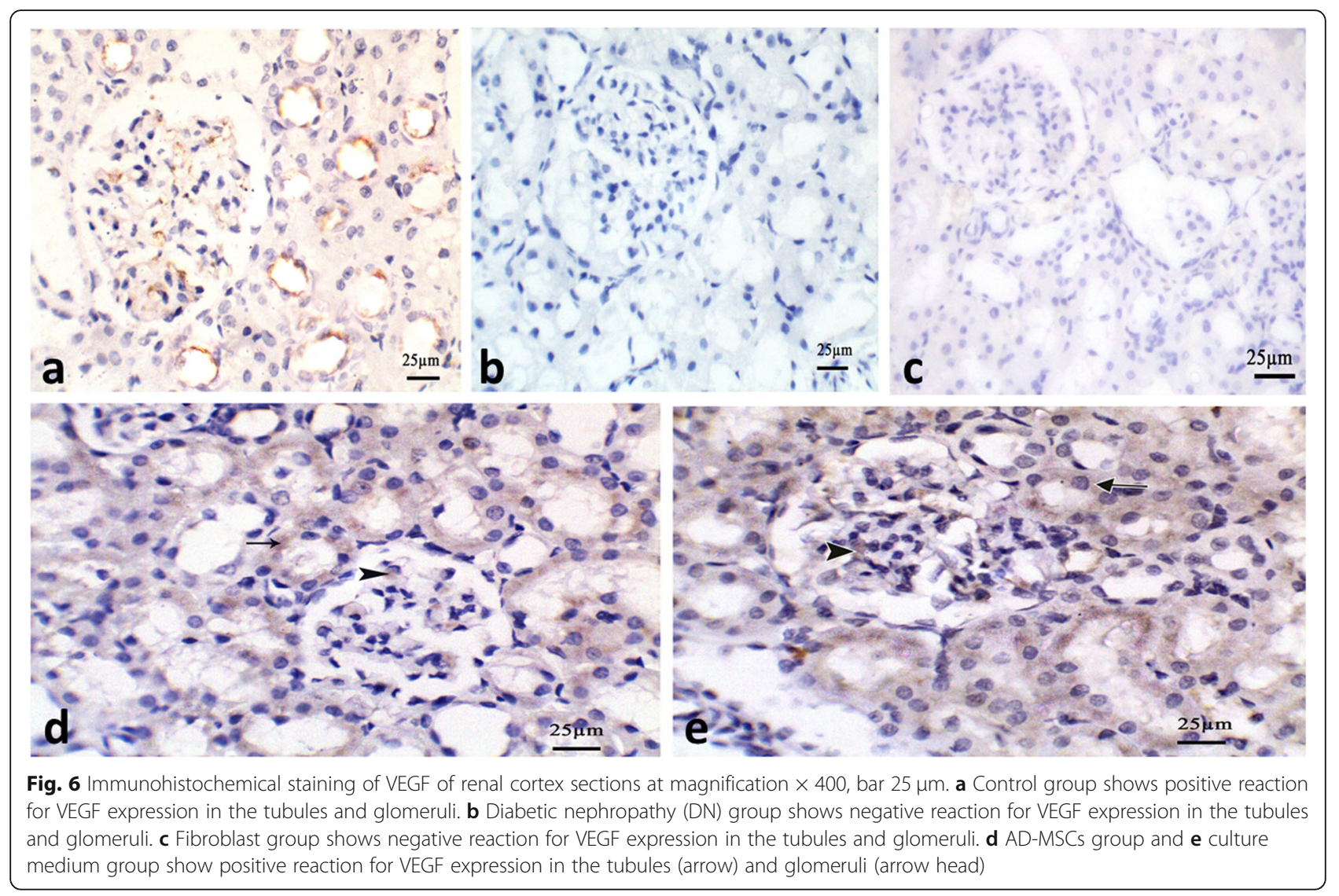

ameliorate the effects of diabetes, and it is possible to avoid cell transplantation in the treatment of DN.

Duffield et al. stated that functional repair is derived from the contribution of BM-DC to regenerative cytokine production [59]. BM-MSCs seemed to contribute to 3 to $22 \%$ of cells regenerating renal tubular [60] and glomerular cell populations [61] that is the majority of reparative cells were derived from intrinsic kidney cells.

Oxidative stress plays a chief role in the pathogenesis of DN in both types of diabetes mellitus, type 1 and 2
$[62,63]$. Evans et al. demonstrated that the main promoting factor for the development of $\mathrm{DN}$ is the increase of oxidative stress, not hyperglycemia itself, and this increase leads to endothelial damage [64]. In the current work, the MSCs and/or CM effectively attenuated the increased levels of lipid peroxidation product (MDA) and improved the decreased concentration of antioxidant parameters such as GSH and CAT in DN. Hyperglycemia contributes to the increased level of advanced glycation end products (AGEs) in diabetic renal

Table 5 Morphometric analysis of urinary space proximal tubules and distal tubules diameters and area percent of connective tissue surrounding the tubules and within the glomeruli in the different studied groups

\begin{tabular}{|c|c|c|c|c|}
\hline Studied groups & $\begin{array}{l}\text { Urinary space diameter (USD) } \\
(\mu \mathrm{m})\end{array}$ & $\begin{array}{l}\text { Proximal tubules diameter (PCD) } \\
(\mu \mathrm{m})\end{array}$ & $\begin{array}{l}\text { Distal tubules diameter } \\
\text { (DCD) }\end{array}$ & $\begin{array}{l}\text { Area percent (AP) } \\
\left(\mu \mathrm{m}^{2}\right)\end{array}$ \\
\hline Control $(n=15)$ & $7.843 \pm 1.66$ & $38.34 \pm 5.77$ & $21.68 \pm 2.76$ & $18.5 \pm 2.83$ \\
\hline $\mathrm{DN}(n=15)$ & $14.33 \pm 2.54^{\mathrm{a}}$ & $44.5470 \pm 5.96$ & $30.38 \pm 2.65^{a}$ & $36.34 \pm 4.48^{a}$ \\
\hline Fibroblast $(n=15)$ & $14.948 \pm 2.14^{\mathrm{a}}$ & $44.25 \pm 5.13$ & $30.63 \pm 2.43^{\mathrm{a}}$ & $36.43 \pm 4.16^{\mathrm{a}}$ \\
\hline AD-MSC $(n=15)$ & $8.04 \pm 1.32^{b, c}$ & $39.21 \pm 5.33$ & $20.84 \pm 2.57^{b, c}$ & $20.55 \pm 2.36^{b, c}$ \\
\hline $\mathrm{CM}(n=15)$ & $8.66 \pm 1.40^{\mathrm{b}, \mathrm{c}}$ & $39.77 \pm 5.81$ & $20.32 \pm 2.61^{b, c}$ & $19.90 \pm 2.46^{b, c}$ \\
\hline$F$ & 13.048 & 3.623 & 44.32 & 98.41 \\
\hline$P$ & 0.000 & 0.011 & 0.000 & 0.000 \\
\hline
\end{tabular}

One-way ANOVA, post hoc tests, $P>0.05$ no significant differences, $P<0.05$ significant differences, and $P<0.001$ highly significant differences

${ }^{a}$ Significant difference vs control group

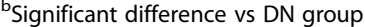

'Significant difference vs fibroblast group 
glomeruli [65], which plays a crucial role in formation of reactive oxygen species (ROS). STZ also significantly elevates the activity of xanthine oxidase, which is considered as another important cause of ROS [7]. Shah et al. showed that ROS could activate nuclear factor-Kappa beta (NF-k $\beta$ ) which upregulate TGF- $\beta 1$ in STZ-induced diabetic kidney dysfunction [66].

TGF- $\beta 1$ is a fibrogenic growth factor, locally produced in the kidney. It participates in progressive renal tubular atrophy by induction of apoptosis in tubular epithelial cells [67]. In this study, the upregulated TGF- $\beta 1$ expression in DN was blunted by MSCs and/or CM. This finding was proved by Mallory trichrome as excess fibrosis appeared in the glomeruli and around tubules in DN group while this fibrosis was markedly decreased in MScs and/or CM group. We suggest that MSCs and/or $\mathrm{CM}$ could hinder hyperglycemia-mediated and ROSinduced activation of NF-kB signal cascade as well as upregulation of TGF- $\beta 1$ in DN.

We tried to focus on the role of TNF- $\alpha$ in diabetic circumstances. It can activate cell survival, extrinsic apoptosis signalling pathways, and stimulation of the kidney epithelial cells to secrete chemo-attractant factors and cell adhesion factors [68]. Moreover, it enhances local production of ROS and alteration of the glomerular capillary barrier function with resulting proteinuria [69, 70]. TNF- $\alpha$ expression levels were lower in MSCs and/ or $\mathrm{CM}$ treated groups as compared with the DN group in the present study.

TNF- $\alpha$ initiates caspase- 8 activation in the cytosol through death receptor, TNF-R1. Caspase- 8 activates either type I or type II pathways of programmed cell death [71]. Caspase-8, in the pathway of type I, directly activates caspase-3, resulting in apoptosis [72, 73]. In type II pathway, the caspase- 8 promotes cell death depending on mitochondria apoptotic pathways via $\mathrm{Bcl}-2$ family protein in the mitochondria [74].

There was a significant elevation in TNF- $\alpha$ levels, caspase- 3 , and caspase- 8 expression levels in DN compared to the control group. MSC and/or CM inhibit this TNF- $\alpha$ apoptotic pathway by decreasing TNF- $\alpha$ levels and caspase-3 and caspase- 8 mRNA levels in DN model. Similar results were recorded for TNF- $\alpha$ [75] and TGF- $\beta$ [76].

ROS enhances oxidative stress with a disturbance in the balance between pro and anti-apoptotic proteins. When the ratio of $\mathrm{Bax} / \mathrm{Bcl}-2$ is elevated, the protective and defensive effects of $\mathrm{Bcl}-2$ are disrupted, particularly on the mitochondrial membrane with increased permeability allowing cytochrome c leakage into the cytosol and activate caspase-3 and 9 [77, 78]. In our study, we found the decreased expression of Bax and increased expression of Bcl-2 in MSCs and/ or CM therapy of DN.

\section{Conclusion}

MSC and/or CM have minimized DN supporting the hypothesis that MSCs may exert a paracrine effect on the damaged tissue. These paracrine effects may be mediated mainly by the RNA-like factors released by MSCs into the medium because the protective effect of the CM was blunted by RNase during a long period of incubation. Therefore, in future clinical applications, it may be possible to treat this $\mathrm{DN}$ using $\mathrm{CM}$ alone, thus avoiding cell transplantations.

\section{Abbreviations \\ AD: Adipose tissue; AGEs: Advanced glycation end products; AP: Area percent; CAT: Catalase; CM: Culture medium; DCD: Distal tubules diameter; DN: Diabetic nephropathy; GSH: Reduced glutathione; MDA: Malondialdehyde; MSCs: Mesenchymal stem cells; NF-kB: Nuclear factor-Kappa beta; NOS: Nitric oxide synthase; PCD: Proximal tubules diameter; ROS: Reactive oxygen species; STZ: Streptozotocin; TGF- $\beta 1$ : Transforming growth factor- $\beta 1$; TNF-a: Tumor necrosis factor-a; USD: Urinary space diameter; VEGF-A: Vascular endothelial growth factor-a}

\section{Acknowledgements}

We would like to thank all members of Medical Biochemistry, Human anatomy \& embryology departments, and Animal house of the faculty for facilitating the performance of this work.

\section{Authors' contributions}

AAl prepared the idea and designed the study; SEA did the data statistical analysis; NR, OA, and NAS performed all the laboratory investigations and interpreted the research data regarding each studied group, and MMM with AAl performed all histological studies. All authors wrote, read, and approve the final manuscript.

\section{Funding}

Not applicable

\section{Availability of data and materials Not applicable}

Ethics approval and consent to participate

This study has been approved by Faculty of Medicine, Zagazig University Institutional Review Board (IRB) for research studies (reference number is 4920/14-7-2016) and Zagazig University IACUC (approval number is ZUIACUC/3/F/90/2018) for animal research.

\section{Consent for publication}

Not applicable

\section{Competing interests}

All authors declared that there are no competing interests.

\section{Author details}

${ }^{1}$ Human Anatomy \& Embryology Department, Faculty of Medicine, Zagazig University, Zagazig, Egypt. ${ }^{2}$ Urology Department, Faculty of Medicine, Zagazig University, Zagazig, Egypt. ${ }^{3}$ Medical Biochemistry Department, National Research Centre, Cairo, Egypt. ${ }^{4}$ Medical Biochemistry Department, Faculty of Medicine, Zagazig University, Zagazig 44512, Egypt.

Received: 23 January 2020 Accepted: 30 April 2020

Published online: 25 May 2020

\section{References}

1. Donate-Correa J, Luis-Rodríguez D, Martín-Núnez E, Tagua VG, HernándezCarballo C, Ferri C, Rodríguez-Rodríguez AE, Mora-Fernández C, NavarroGonzález JF (2020) Inflammatory targets in diabetic nephropathy. J Clin Med 9:458

2. Kanwar YS, Wada J, Sun L et al (2008) Diabetic nephropathy: mechanisms of renal disease progression. ExpBiol Med (Maywood) 233:4-11 
3. Soldatos G, Cooper ME (2008) Diabetic nephropathy: important pathophysiologic mechanisms. Diabetes Res Clin Pract 82:S75-S79

4. Forbes JM, Fukami K, Cooper ME (2007) Diabetic nephropathy: where hemodynamics meets metabolism. Exp Clin Endocrinol Diabetes 115:69-84

5. Bonnefont-Rosselot $D$ (2004) The role of antioxidant micronutrients in the prevention of diabetic complications. Treat Endocrinol 3(1):41-52

6. Brownlee M (2001; Dec 13) Biochemistry and molecular cell biology of diabetic complications. Nature 414(6865):813-820

7. Forbes JM, Coughlan MT, Cooper ME (2008) Oxidative stress as a major culprit in kidney disease in diabetes. Diabetes 57(6):1446-1454

8. Motyl K, McCabe LR (2009) Streptozotocin, type I diabetes severity and bone. Biol Proced Online 11:296-315. https://doi.org/10.1007/s12575-0099000-5

9. Burney BO, Kalaitzidis RG, Bakris GL (2009) Novel therapies of diabetic nephropathy. Curr Opin Nephrol Hypertens 18:107-111

10. Qi Y, Ma J, Li S et al (2019) Applicability of adipose-derived mesenchymal stem cells in treatment of patients with type 2 diabetes. Stem Cell Res Ther 10:274. https://doi.org/https://doi.org/10.1186/s13287-019-1362-2

11. Locke M, Windsor J, Dunbar PR (2009) Human adipose-derived stem cells: isolation, characterization, and applications in surgery. ANZ J Surg 79(4): 235-244

12. Zhao Q, Ren H, Han Z (2016) Mesenchymal stem cells: immunomodulatory capability and clinical potential in immune diseases. J Cell Immunother 2:320

13. Rawat S, Gupta S, Mohanty S (2019) Mesenchymal stem cells modulate the immune system in developing therapeutic interventions. Immune response activation and immunomodulation book. https://doi.org/10.5772/ intechopen.80772

14. Keller CA, Gonwa TA, Hodge DO, Hei DJ, Centanni JM, Zubair AC (2018) Feasibility, safety, and tolerance of mesenchymal stem cell therapy for obstructive chronic lung allograft dysfunction. Stem Cells Transl Med 7:161167. https://doi.org/10.1002/sctm.17-0198

15. Lukomska B, Stanaszek L, Zuba-Surma E, Legosz P, Sarzynska S, Drela K (2019) Challenges and controversies in human mesenchymal stem cell therapy. Stem Cells Int 2019:9628536

16. Morigi M, Imberti B, Zoja C, Corna D, Tomasoni S, Abbate M, Rottoli D, Angioletti S, Benigni A, Perico N, Alison M, Remuzzi G (2004) Mesenchymal stem cells are renotropic, helping to repair the kidney and improve function in acute renal failure. J Am SocNephrol 15(7):1794-1804

17. Lin F, Moran A, Igarashi P (2005) Intra-renal cells, not bone marrow-derived cells, are the major source for regeneration in postischemic kidney. J Clin Invest 115(7):1756-1764

18. Zhang M, Mal N, Kiedrowski M, Chacko M, Askari AT, Popovic ZB, Koc ON, Penn MS (2007) SDF-1 expression by mesenchymal stem cells results in trophic support of cardiac myocytes after myocardial infarction. FASEB J 21(12):3197-3207

19. Togel F, Weiss K, Yang Y, Hu Z, Zhang P, Westenfelder C (2007) Vasculotropic, paracrine actions of infused mesenchymal stem cells are important to the recovery from acute kidney injury. Am J Physiol Renal Physiol 292(5):F1626-F3165

20. Shulman K, Rosen S, Tognazzi K, Manseau EJ, Brown LF. Expression of vascular permeability factor (VPFNEGF) is altered in many glomerular diseases. J Am SocNephrol 1996; 7:661-666. [PubMed: 8738799].

21. Hohenstein B, Hausknecht B, Boehmer K, Riess R, Brekken RA, Hugo CP. Local VEGF activity but not VEGF expression is tightly regulated during diabetic nephropathy in man. Kidney Int 2006; 69:1654-1661. [PubMed: 16541023].

22. Brosius FC 3rd, Alpers CE, Bottinger EP, et al. Animal models of diabetic complications consortium. Mouse models of diabetic nephropathy. J Am SocNephrol. 2009; 20:2503-2512. [PubMed: 19729434].

23. Brosius FC, Khoury CC, Buller CL, Chen S (2010) Abnormalities in signaling pathways in diabetic nephropathy. Expert Rev Endocrinol Metab 5:51-64

24. Domouky AM, Hegab AS, Al-Shahat A, Raafat N (2017) Mesenchymal stem cells and differentiated insulin producing cells are new horizons for pancreatic regeneration in type I diabetes mellitus. Int J Biochem Cell Biol 87:77-85

25. Fang Y, Tian X, Bai S, Fan J, Hou W, Tong H, Li D (2012) Autologous transplantation of adipose-derived mesenchymal stem cells ameliorates streptozotocin-induced diabetic nephropathy in rats by inhibiting oxidative stress, pro-inflammatory cytokines and the p38 MAPK signaling pathway. Int J Mol Med 30:85-92
26. Ni W, Fang Y, Xie L, Liu X, Shan W, Zeng R, Liu J, Liu X (2015 Nov) Adiposederived mesenchymal stem cells transplantation alleviates renal injury in streptozotocin-induced diabetic nephropathy. J Histochem Cytochem 63(11):842-853. https://doi.org/10.1369/0022155415599039

27. Raafat N, Abdel Aal SM, Abdo FK, El Ghonaimy NM (2015) Mesenchymal stem cells: in vivo therapeutic application ameliorates carbon tetrachlorideinduced liver fibrosis in rats. Int J Biochem Cell Biol 68:109-118

28. Bhang SH, Lee S, Shin JY, Lee TJ, Jang HK, Kim BS (2014; Apr) Efficacious and clinically relevant conditioned medium of human adipose-derived stem cells for therapeutic angiogenesis. Mol Ther 22(4):862-872. https://doi.org/ 10.1038/mt.2013.301

29. Lambert JF, Benoit BO, Colvin GA et al (2000) Quick sex determination of mouse fetuses. J Neurosci Methods 95:127-132

30. Yoshida K, Ono M, Maejima T, Esaki M, Sawada H (2007) Oligopotent mesenchymal stem cell-like clone becomes multinucleated following phorbol ester, TPA stimulation. Anat Rec 120:1256-1267

31. Scott E, Fawcett JK (1960) A rapid and precise method for the determination of urea. J Clin Pathol 13(2):156-159

32. Henry R (1974) Clinical chemistry principles and techniques, second edn. Harper and Ow, New York

33. Ohkawa H, Ohishi N, Yagi K (1979) Assay for lipid peroxides in animal tissues by the thiobarbituric acid reaction. Anal Biochem 95(2):351-358

34. Beutler E, Duron O, Kelly BM (1963) Improved method for the determination of blood glutathione. J Lab Clin Med 61:882-888

35. Aebi H (1974) Catalase. In: Bergmeyer HU (ed) Methods of enzymatic analysis. Academic press. NY, USA, New York, pp 673-677

36. Bradford MM.A Rapid and sensitive method for the quantitation of microgram quantities of protein utilizing the principle of protein-dye binding.Anal Biochem 1976; 72: 248-254.

37. Li CP, Li JH, He SY, Li P, Zhong XL (2014) Roles of Fas/Fasl, BCl-2/Bax, and caspase-8 in rat nonalcoholic fatty liver disease pathogenesis. Genet Mol Res 13(2):3991-3999

38. Hua P, Liu J, Tao J, Liu J, Yang S (2015) Influence of caspase-3 silencing on the roliferation and apoptosis of rat bone marrow mesenchymal stem cells under hypoxia. Int J ClinExp Med 8(2):1624-1633

39. Kiernan JA (2001) Histological and histochemical methods: theory and practice, 3rd edn. Arnold publisher, London, pp 111-162

40. Malatiali S, Francis S, Barac-Nieto M (2008) Phlorizin prevents glomerular hyperfiltration but not hypertrophy in diabetic rats. Exp Diabetes Res:305313

41. Bancroft J, Gamble A (2008) Theory and practice of histological techniques, 6th edn. Churchill Livingstone, New York, London, pp 165-175

42. Bancroft JD, Cook HC (1994) Immunocytochemistry. In: Bancroft JD, Cook HC, Turner DR (eds) Manual of histological techniques and their diagnostic application, 2nd edn. Churchill Livingstone, New York: Edinburgh, pp 263325

43. Villegas G, Lange-Sperandio GB, Tufro A (2005) Autocrine and paracrine functions of vascular endothelial growth factor (VEGF) in renal tubular epithelial cells. Kidney Int 67:449-457

44. Ezquer FE, Ezquer ME, Parrau DB et al (2008) Systemic administration of multipotent mesenchymal stromal cells reverts hyperglycemia and prevents nephropathy in type 1 diabetic mice. Biol Blood Marrow Transplant 14:631640

45. Anglani F, Forino M, Del Prete D, Tosetto E, Torregrossa R, D'Angelo A (2004) In search of adult renal stem cells. J Cell Mol Med 8(4):474-487

46. Najafian B, Alpers CE, Fogo AB (2011) Pathology of human diabetic nephropathy. Contrib Nephrol 170:36-47

47. Raparia K, Usman I, Kanwar YS (2013) Renal morphologic lesions reminiscent of diabetic nephropathy. Arch Pathol Lab Med 137:351-359

48. Kim HJ, Kong MK, Kim YC (2008) Beneficial effects of Phellodendri cortex extract on hyperglycemia and diabetic nephropathy in streptozotocininduced diabetic rats. BMB Rep 41(10):710-715

49. Zafar M, Naeem-ul-Hassan Naqvi S, Ahmed M, Kaimkhani ZA (2009) Altered kidney morphology and enzymes in streptozotocin-induced diabetic rats. Int J Morphol 27(3):783 -790, 2009

50. Wong CY, Cheong SK, Mok PL, Leong CF (2008) Differentiation of human mesenchymal stem cells into mesangial cells in post-glomerular injury murine model. Pathology 40:52-57

51. Qian H, Yang H, Xu W, Yan Y, Chen Q et al (2008) Bone marrow mesenchymal stem cells ameliorate rat acute renal failure by differentiation into renal tubular epithelial-like cells. Int J Mol Med 22:325-332 
52. Wu HJ (2014) Yiu WH, Li RX, Wong DW, Leung JC, et al. Mesenchymal stem cells modulate albumin-induced renal tubular inflammation and fibrosis Plos One 9:e90883

53. Park JH, Hwang I, Hwang SH, Han H, Ha H (2012) Human umbilical cord blood-derived mesenchymal stem cells prevent diabetic renal injury through paracrine action. Diabetes Res Clin Pract 98:465-473

54. Lv SS, Liu G, Wang JP, Wang WW, Cheng J et al (2013) Mesenchymal stem cells transplantation ameliorates glomerular injury in streptozotocin induced diabetic nephropathy in rats via inhibiting macrophage infiltration. Int Immunopharmacol 17:275-282

55. Ling $L$, Truong $P$, Igarashi $P$, Lin $F(2007)$ Renal and bone marrow cells fuse after renal ischemic injury. J Am Soc Nephrol 18(12):3067-3077

56. Rookmaaker MB, Verhaar MC, de Boer HC, Goldschmeding R, Joles JA, Koomans HA, Gröne HJ, Rabelink TJ (2007) Met-RANTES reduces endothelial progenitor cell homing to activated (glomerular) endothelium in vitro and in vivo. Am J Physiol Renal Physiol 293(2):F624-F630

57. Ito T, Suzuki A, Okabe M, Imai E, Hori M (2001) Application of bone marrowderived stem cells in experimental nephrology. Exp Nephrol 9(6):444-450

58. Bruno S, Grange C, Deregibus MC, Calogero RA, Saviozzi S et al (2009) Mesenchymal stem cell-derived microvesicles protect against acute tubular injury. J Am Soc Nephrol 5:1053-1067

59. Duffield JS, Bonventre JV (2005) Kidney tubular epithelium is restored without replacement with bone marrow-derived cells during repair after ischemic injury. Kidney Int 68(5):1956-1961

60. Chishti AS, Sorof JM, Brewer ED, Kale AS (2001) Long-term treatment of focal segmental glomerulosclerosis in children with cyclosporine given as a single daily dose. Am J Kidney Dis 38(4):754-760

61. Poulsom R, Forbes SJ, Hodivala-DHke K, Ryan E, Wyles S, Navaratnarasah S, Jeffery R, Hunt T, Alison M, Cook T, Pusey C, Wright NA (2001) Bone marrow contributes to renal parenchymal turnover and regeneration. J Pathol 195(2):229-235

62. Baynes JW, Thorpe SR (1999) Role of oxidative stress in diabetic complications: a new perspective on an old paradigm. Diabetes 48(1):1-9

63. Chen HC, Guh JY, Chang JM, Hsieh MC, Shin SJ, Lai YH (2005) Role of lipid control in diabetic nephropathy. Kidney Int 94(Suppl):S60-S62

64. Bigagli E, Lodovici M (2019) Circulating oxidative stress biomarkers in clinical studies on type 2 diabetes and its complications. Oxid Me Cell Longev 2019:5953685

65. Horie K, Miyata T, Maeda K, Miyata S, Sugiyama S, Sakai H, van Ypersole de Strihou C, Monnier VM, Witztum JL, Kurokawa K (1997) Immunohistochemical co-localization of glycoxidation products and lipid peroxidation products in diabetic renal glomerular lesions. Implication for glycoxidative stress in the pathogenesis of diabetic nephropathy. J Clin Invest 100(12):2995-2999

66. Ratliff BB, Abdulmahdi W, Pawar R, Wolin MS (2016) Antioxidants \& redox signaling. Jul:119-146

67. Tunçdemir M, Oztürk M (2011) The effects of angiotensin-II receptor blockers on podocyte damage and glomerular apoptosis in a rat model of experimental streptozotocin-induced diabetic nephropathy. Acta Histochem 113(8):826-832

68. Carlos CP, Sliva AA, Gil CD, Oliani SM (2018) Pharmacological treatment with galectin-1 protects against renal ischaemia-reperfusion injury. Sci Rep 8: 9568. https://doi.org/10.1038/s41598-018-27907-y

69. Sverrisson K, Axelsson J, Rippe A, Asgeirsson D, Rippe B (2015 Aug) Acute reactive oxygen species (ROS)-dependent effects of IL-1, TNF-, and IL-6 on the glomerular filtration barrier (GFB) in vivo. Am J Physiol Renal Physiol 309:F800-F806. https://doi.org/10.1152/ajprenal.00111.2015

70. Koike N, Takamura T, Kaneko S (2007) Induction of reactive oxygen species from isolated rat glomeruli by protein kinase $\mathrm{C}$ activation and TNF-a stimulation, and effects of a phosphodiesterase inhibitor. Life Sci 80(18): 1721-1728

71. Budihardjo I, Oliver H, Lutter M, Luo X, Wang X (1999) Biochemical pathways of caspase activation during apoptosis. Annu Rev Cell DevBiol 15: 269-290

72. Lavrik IN, Krammer PH (2012 Jan) Regulation of CD95/Fas signaling at the DISC. Cell Death Differ 19(1):36-41. https://doi.org/10.1038/cdd.2011.155

73. Sinha K, Pal PB, Sil PC (2014) Cadmium (Cd2+) exposure differentially elicits both cell proliferation and cell death related responses in SK-RC-45. Toxicol in Vitro 28:307-318
74. Luo X, Budihardjo I, Zou H, Slaughter C, Wang X (1998) Bid, a Bcl2 interacting protein, mediates cytochrome $\mathrm{c}$ release from mitochondria in response to activation of cell surface death receptors. Cell 94(4):481-490

75. Sun W, Cao C, Huang W, Chen W, Yasser G, Sun D, Wan X (2016) Interleukin-10 deficiency increases renal inflammation and fibrosis in a mouse ischemia-reperfusion injury model. Int J Clin Exp Pathol 9(3):30373043

76. Semedo P, Palasio CG, Oliveira CD, Feitoza CQ, Gonçalves GM, Cenedeze MA, Wang PM, Teixeira VP, Reis MA, Pacheco-Silva A, Câmara NO (2009) Early modulation of inflammation by mesenchymal stem cell after acute kidney injury. IntImmunopharmacol 9(6):677-682

77. Lawen A (2005) Apoptosis- an introduction. BioEssays 2003; 25 (9): 888-896. Togel F, Hu Z, Weiss K, Isaac J, Lange C, Westenfelder C. administered mesenchymal stem cells protect against ischemic acute renal failure through differentiation-independent mechanisms. Am J Physiol Renal Physiol 289(1):F31-F42

78. Togel F, Hu Z, Weiss K, Isaac J, Lange C, Westenfelder C (2005) Administered mesenchymal stem cells protect against ischemic acute renal failure through differentiation-independent mechanisms. Am J Physiol Renal Physiol 289(1):F31-F42

\section{Publisher's Note}

Springer Nature remains neutral with regard to jurisdictional claims in published maps and institutional affiliations.

\section{Submit your manuscript to a SpringerOpen ${ }^{\circ}$ journal and benefit from:}

- Convenient online submission

- Rigorous peer review

- Open access: articles freely available online

High visibility within the field

- Retaining the copyright to your article

Submit your next manuscript at $>$ springeropen.com 